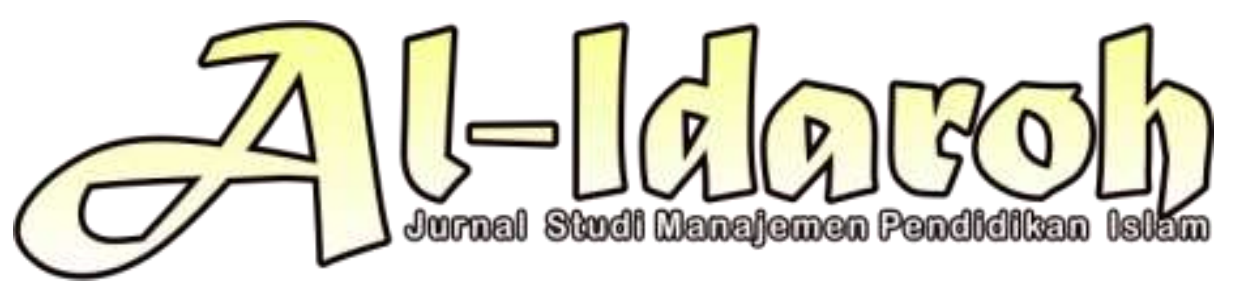

\title{
IMPLEMENTASI KEBIJAKAN PROGRAM INDONESIA PINTAR (PIP) DI WILAYAH KEMENTERIAN AGAMA KABUPATEN SIDOARJO
}

\author{
Lilik Fadzlun \\ Universitas Islam Negeri Sunan Ampel Surabaya \\ Email: fadzlunlilik0@gmail.com \\ Zaidatun Ni'mah \\ Universitas Islam Negeri Sunan Ampel Surabaya \\ Email: zaidatun02@gmail.com \\ Lindah Ayu L \\ Universitas Islam Negeri Sunan Ampel Surabaya \\ Email: lindahayu.240@gmail.com \\ Lilik Huriyah \\ Universitas Islam Negeri Sunan Ampel Surabaya \\ Email: lilikhuriyah@uinsby.ac.id
}

\author{
Abdul Rahman \\ Kasi Pendidikan Madrasah Kemenag Kabupaten Sidoarjo \\ Email: rahmanabdul9564@gmail.com
}

\begin{abstract}
Abstrak: This study aims to identify and describe the implementation of the Smart Indonesia Program Policy or Program Indonesia Pintar (PIP) in the area of the Ministry of Religion, Sidoarjo Regency. The research method used is qualitative research. Data collection techniques used interviews, observation, and documentation with informants, namely application managers to verify the Smart Indonesia Program. Data analysis techniques are data reduction, data presentation and conclusions. The results showed that the Program Indonesia Pintar (PIP) carried out at the Ministry of Religion Office of Sidoarjo Regency was running well so that it could verify student data data to get financial assistance. Students who have registered at educational institutions with KIP, KKS, PKH, as well as parents who have been laid off. This program aims to help parents who are vulnerable to poverty in order to get a good education and prevent dropouts. Every year the funds are disbursed in registered student accounts.
\end{abstract}

Keywords: Policy Implementation, Program Indonesia Pintar (PIP) 


\section{Pendahuluan}

Pendidikan merupakan hal yang sangat penting. Sebab pendidikan dijadikan instrumen dalam penentuan kontribusi terhadap kemajuan suatu bangsa. Tujuan pendidikan Nasional di Indonesia tertuang dalam pembukaan Undang-Undang Dasar 1945 pada alenia ke-4 yaitu mencerdaskan kehidupan bangsa. Lebih lanjut pasal 1 mengamanatkan bahwa setiap warga negara berhak untuk mendapatkan pendidikan yang difasilitasi oleh pemerintah sebagai pihak penyelenggara sistem pendidikan nasional ${ }^{1}$. Banyaknya anak-anak yang putusnya pendidikan dikarenakan faktor yang kurang mendukung terhadap pendidikan yaitu kemiskinan. Beberapa kali kemiskinan dijauhkan dengan pendidikan sehingga banyak masyarakat kurang mampu tidak dapat dan tidak bisa mendapatkan pendidikan. Kemiskinan dapat menyebabkan terbatasnya masyarakat untuk mendapatkan sebuah pendidikan, padahal pendidikan ditujukan untuk membantu masyarakat keluar dari beratnya kemiskinan. Kemiskinan inilah yang menyebabkan pendidikan Indonesia kurang merata, dan kemiskinan inilah salah satu permasalahan yang ada pada pendidikan di Indonesia.

Pemerintah meningkatkan akses pendidikan kepada masyarakat khususnya pada siswa-siswi yang berasal dari keluarga kurang mampu. Dalam Peraturan Menteri Pendidikan dan Kebudayaan Republik Indonesia Nomor 12 Tahun 2015 yang kemudian diperbarui menjadi Peraturan Menteri Pendidikan Dan Kebudayaan Republik Indonesia nomor 19 tahun 2016 tentang Program Indonesia Pintar pasal 1, Program Indonesia Pintar untuk selanjutnya disebut PIP adalah bantuan berupa uang tunai dari pemerintah yang diberikan kepada peserta didik yang orang tuanya tidak mampu membiayai pendidikannya ${ }^{2}$. Berdasarkan ketentuan tersebut maka pemerintah mereancang Program Indonesia Pintar (PIP) yang dimaksudkan untuk membantu anak-anak dari keluarga miskin agar merka mendapatkan pendidikan yang layak.

Program Indonesia Pintar merupakan program unggulan pemerintah yang bertujuan untuk menjamin keberlangsungan akses pendidikan anak-anak usia sekolah

\footnotetext{
${ }^{1}$ Retnaningsih Hartini, Program Indonesia Pintar: Implementasi Kebijakan Jaminan Sosial Bidang Pendidikan (Studi di Kota Kupang, Provinsi Nusa Tenggara Timur dan Kota Palembang, Provinsi Sumatera Selatan. (Jurnal Aspirasi Vol 8 No. 2 Desember 2017)

${ }^{2}$ Retnaningsih Hartini, Program Indonesia Pintar: Implementasi Kebijakan Jaminan Sosial Bidang Pendidikan (Studi di Kota Kupang, Provinsi Nusa Tenggara Timur dan Kota Palembang, Provinsi Sumatera Selatan. (Jurnal Aspirasi Vol 8 No. 2 Desember 2017)
} 


\section{Implementasi Kebijakan Program Indonesia Pintar (PIP) di Wilayah Kementerian Agama Kabupaten Sidoarjo}

dari keluarga prasejahtera. Yang diantaranya melalui Program Indonesia Pintar sebagai penyempurnaan dari program bantuan siswa miskin. Program Indonesia Pintar (PIP) merupakan pemberian bantuan tunai pendidikan bagi anak usia sekolah dari keluarga pemegang Kartu Keluarga Sejahtera (KKS) atau Kartu Indonesia Pintar $(\mathrm{KIP})^{3}$. Program ini nantinya mengharapkan anak usia 6 sampai 21 tahun untuk dapat memperoleh pendidikan sampai tamat pendidikan menengah dan mencegah atau menarik peserta didik putus sekolah ${ }^{4}$.

Program Indonesia Pintar ini bertujuan untuk membantu biaya personal pendidikan bagi peserta didik miskin atau rentan miskin yang masih terdaftar sebagai peserta didik pada jenjang pendidikan dasar dan menengah. Oleh karena itu program tersebut sangatlah membantu agar peserta didik tetap mendapatkan pendidikan yang layak. Dengan adanya program tersebut dana PIP dimanfaatkan oleh siswa untuk membeli kebutuhan perlengkapan sekolah seperti membeli seragam sekolah, alat tulis serta buku. Program Indonesia Pintar memiliki peran yang sangat penting bagi dunia pendidikan. Pertama sebagai aksebilitas pendidikan yang membantu pemerataan dalam mengakses pendidikan, sehingga peserta didik yang berasal dari keluarga kurang mampu dapat mengakses pendidikan. Kebijakan Program Indonesia Pintar (PIP) diluncurkan oleh pemerintah. Tujuan dari program tersebut adalah untuk membantu siswa miskin untuk memperoleh pendidikan yang layak, mencegah putusnya sekolah, serta untuk memenuhi kebutuhan sekolah ${ }^{5}$. Diharapkan dengan adanya bantuan tersebut tidak ada lagi siswa-siswi yang putus sekolah. Dengan program PIP ini diharapkan data tentang siswa sekolah di Indonesia dapat terpotret dengan baik, sehingga pemerintah tepat sasaran dalam memberikan bantuan pendidikan bagi pihak-pihak yang membutuhkan.

Harapan pemerintah tentang Program PIP itupun direalisasikan oleh Kementerian Agama Kabupaten Sidoarjo. Dengan program PIP, Kementerian Agama Kabupaten Sidoarjo berupaya untuk memotret kondisi riil siswa yang ada di

${ }^{3}$ Isyad Zamjani, Pelaksanaan Program Indonesia Pintar Bagi Penerima Kartu Indonesia Pintar Reguler : Studi di Empat Daerah Kunjungan Kerja Presiden Tabun 2017, (Jurnal: Penelitian Kebijakan Pendidikan. Vol 11 No 2 Agustus 2018) 67

${ }^{4}$ Wirastiana binti Yusup, dkk, Evaluasi Indonesia Pintar dalam Peningkatan Akses Pendidikan di Sekolah Menengah Pertama, (Jurnal Manajemen Pendidikan Vol 6 No 1 Januari-Juni 2019), 44

${ }^{5}$ N.Eni Rohaeni, Oyon Saryono, Implementasi Kebijakan Program Indonesia Pintar (PIP) Melalui kartu Indonesia Pintar (KIP) dalam Upaya Pemerataan Pendidikan. (Journal of education management\& administration review June 2018. Vol 2 No 1). 194 
masyarakat kabupaten Sidoarjo. Meski dalam implementasinya, tak jarang masih terdapat kendala pada sistem e-PIP atau web untuk mengakses Program Indonesia Pintar. Banyaknya lembaga yang kurang memperhatikan dalam pengisian biodata siswa yang telah ditentukan oleh pemerintah. Sehingga membuat admin yang memverifikasi data tersebut terhambat untuk menyetujui guna mendapatkan bantuan Program Indonesia Pintar.

Dalam pengajuan Program Indonesia Pintar dapat melalui lembaga salah satunya yaitu Kantor Kementerian Agama Kabupaten Sidoarjo. Di Kantor Kementerian Agama tersebut sebagai perantara untuk lembaga yang mengajukan Program Indonesia Pintar agar memperoleh bantuan tersebut. Pada penelitian ini satuan lembaga yang memperoleh bantuan Program Indonesia Pintar yaitu lembaga Madrasah Ibtidaiyah (MI), Madrasah Tsanawiyah (MTS), serta Madrasah Aliyah (MA). Program Indonesia Pintar adalah salah satu kebijakan jaminan sosial di bidang pendidikan yang bertujuan untuk memberikan bantuan kepada siswa-siswi dari kalangan kurang mampu. Penelitian Program Indonesia Pintar di wilayah Kantor Kementerian Agama Kabupaten Sidoarjo bertujuan untuk mengetahui proses pelaksanaan, verifikasi, penyaluran bantuan dana, dan evaluasi program PIP.

\section{Metode Penelitian}

Penelitian ini menggunakan pendekatan kualitatif deskriptif, karena pendekatan ini berupaya untuk menemukan dan memahami sebuah fenomena secara menyeluruh ${ }^{6}$. Penelitian kualitatif ini dilakukan secara intensif yaitu peneliti ikut berpartisipasi aktif di lapangan, mencatat secara hati-hati apa yang terjadi, melakukan analisis terhadap berbagai dokumen yang ditemukan di lapangan dan membuat laporan penelitian secara detail ${ }^{7}$. Penelitian kualitatif adalah metode penelitian yang alami, peneliti sebagai instrumen kunci, data yang dihasilkan bersikap deskriptif dan analisis data dilakukan secara induktif. Penelitian kualitatif juga dimaknai sebagai

\footnotetext{
${ }^{6}$ Yudi Agusma, Implementasi Program Indonesia Pintar di Sekolah Dasar Negeri 1 Kolakaasi Kabupaten Kolaka. (Public Inspirasion Juranl Administrasi Publik Vol 4 No 2), 109

7 Sugiyono, Cara Mudab Menyusun Skripsi, (Bandung : Penerbit Alfabeta, 2016), 228-231
} 


\section{Implementasi Kebijakan Program Indonesia Pintar (PIP) di Wilayah Kementerian Agama Kabupaten Sidoarjo}

prosedur penelitian yang menghasilkan data deskriptif berupa kata-kata atau lisan dari orang orang dan berperilaku yang dapat diamati ${ }^{8}$.

Informan dalam penelitian ini adalah pegawai yang bertugas pengelolaan Program Indonesia Pintar (PIP). Lokasi penelitian adalah di Kantor Kementerian Agama Kabupaten Sidoarjo. Metode pengumpulan data pada penelitian ini adalah wawancara, observasi, dan dokumentasi. Peneliti mengajukan berbagai pertanyaan kepada responden secara langsung. Metode pengumpulan data dengan tanya jawab dikerjakan dengan sistematis dan berlandaskan kepada tujuan peneliti. Metode ini bertujuan untuk memperoleh informasi dari informan. Metode berikutnya adalah observasi, yakni peneliti melakukan pengamatan terhadap kejadian, gerak atau proses secara langsung. Observasi dilakukan oleh peneliti untuk mendapatkan sebuah data tentang pelaksanaan PIP dan evaluasi PIP di Kementerian Agama Kabupaten Sidoarjo. Metode pengumpulan data yang terakhir adalah dokumetasi. Peneliti mengumpulkan rekaman informasi baik berupa tulisan, alfanumerik, gambar, maupun sesuatu yang didengar tentang pelaksanaan dan evaluasi PIP di Kementerian Agama Kabupaten Sidoarjo.

Proses yang dilakukan saat analisis data peneliti adalah reduksi data, penyajian data, dan kesimpulan. Pada teknik reduksi data, peneliti merangkum, menyederhanakan data-data yang diperoleh selama penelitian di lapangan. Selain itu peneliti juga memilih hal-hal yang pokok, serta fokus pada hal-hal yang penting. Selanjutnya penyajian data. Penyajian data yaitu merupakan sekumpulan informasi tersusun yang memberi beberapa kemungkinan adanya penarikan kesimpulan. Bentuk penyajian data kualitatif berupa teks naratif (bentuk catatan lapangan). Dan yang terakhir adalah menarik kesimpulan. Kesimpulan adalah tahap akhir dalam proses analisis data. Hasil analisis yang dapat digunakan untuk mengambil tindakan. Dengan demikian kesimpulan dalam penelitian kualitatif mungkin dapat menjawab rumusan masalah yang telah dirumuskan sejak awal.

${ }^{8}$ Sandu Siyoto, Ali Sodik, Dasar Metodologi Penelitian, (Yogyakarta : Literasi Media Publishing, 2015), 27 


\section{HASIL DAN DISKUSI}

\section{Implementasi Kebijakan Program Indonesia Pintar di Kementerian Agama}

\section{Kabupaten Sidoarjo}

Implementasi adalah suatu tindakan atau pelaksanaan dari sebuah rencana yang sudah disusun secara matang dan terperinci, implementasi biasanya dilakukan setelah perencanaan yang sudah dianggap sempura ${ }^{9}$. Program Indonesia Pintar (PIP) adalah program yang merupakan kerja sama tiga kementerian yaitu Kementerian Pendidikan Dan Kebudayaan (Kemendikbud), Kementerian Sosial (Kemensos), Kementerian Agama (Kemenag) ${ }^{10}$. Program Indonesia Pintar (PIP) dirancang untuk membantu anak-anak usia sekolah dari keluarga miskin atau rentan agar tetap mendapatkan layanan pendidikan sampai taman pendidikan menengah, baik melalui jalur formal maupun non-formal ${ }^{11}$.

Hasil penelitian ini adalah untuk mengetahui dan mendeskripsikan Implementasi Kebijakan Program Indonesia Pintar di Kantor Kementerian Agama Kabupaten Sidoarjo. Di setiap madrasah terdapat salah satu pegawai yang menangani program bantuan Program Indonesia Pintar. Lembaga dapat mengajukan melalui Kantor Kementerian Agama Kabupaten Sidoarjo. Madrasah dapat mempersiapkan berkas-berkas yang sudah ditentukan oleh pusat. Selanjutnya sekolah dapat memasuki program melalui aplikasi emis yang sudah disediakan. Setiap sekolah memiliki akun sendiri untuk mengakses program tersebut. Kantor Kementerian Agama Kabupaten Sidoarjo sebagai perantara bagi lembaga yang mendapatkan Program Indonesia Pintar.

Terdapat empat tahap dalam Program PIP. Tahap pertama pada bulan April, tahap dua bulan Juni, tahap tiga dan empat bulan September Oktober. Penyaluran PIP melalui rekening yang telah disediakan oleh pusat. Setiap siswa mendapatkan rekening bank untuk mendapatkan bantuan tersebut. Kementeriam Agama Pusat bekerjasama dengan bank BNI dan BRI. Penggunaan bank BRI untuk tingkat

${ }^{9}$ Ali Mustofa, Andi Prayoga, Konsepsi Implementasi Sistem Informasi Managemen Dalam Mendukung Pelayanan Tenaga Pendidik. Al-Idaroh: Jurnal Studi Manajemen Pendidikan Islam. Vol 4 No 1 Maret 2020

${ }^{10}$ Irawan Suntoro, dll, Kebijakan Publik, (Yogyakarta, Graha Ilmu, 2015), 79

${ }^{11}$ Lilis Novia Saraswati, Implementasi Kebijakan Program Indonesia Pintar (PIP) Pada Jenjang Sekolah Dasar Di Kecamatan Sungai Pinang Kota Samarinda, (Jurnal Administrasi Negara, Vol 5 No 4 2017), 6470 


\section{Implementasi Kebijakan Program Indonesia Pintar (PIP) di Wilayah Kementerian Agama Kabupaten Sidoarjo}

Madrasah Ibtidaiyah (MI), sedangkan bank BNI tingkat Madrasah Tsanawiyah (MTs) dan Madrasah Aliyah (MA).

Persyaratan untuk mendapatkan bantuan PIP adalah harus memenuhi persyaratan yang telah ditentukan meliputi: (1). KKS (Kartu Keluarga Sejahtera). Kartu Keluarga Sejahtera merupakan kartu yang diterbitkan pemerintah untuk rumah tangga/keluarga miskin serta bisa mendaftar melalui desa. Kartu Keluarga Sejahtera (KKS) ini digunakan sebagai alat transaksi untuk memanfaatkan program bantuan. Program bantuan yang diberikan oleh pemerintah diberikan kepada masyarakat miskin seperti, Bantuan Pangan Non Tunai (BPNT) merupakan program pengganti raskin yaitu bantuan sosial seperti beras, gula, minyak, dl1 ${ }^{12}$. (2). KIP (Kartu Indonesia Pintar). Kartu Indonesia Pintar merupakan bentuk pelaksanaan Program Indonesia Pintar dari Dinas Sosial dan Kemenag. Diberikan sebagai penada dan digunakan untuk menjamin serta memastikan seluruh anak sekolah dari keluarga pemegang KKS untuk mendapatkan PIP bila terdaftar di Madrasah. Kartu Indonesia Pintar bertujuan menghilangkan halangan bagi anak usia sekolah/siswa kurang mampu agar memperoleh akses pelayanan pendidikan yang berkualitas, mencegah angka putus sekolah. (3). PKH (Program Keluarga Harapan). Program Keluarga Harapan bisa daftar melalui dari desa. Program pemberian bantuan sosial bersyarat kepada keluarga miskin. Sasaran dari PKH dengan merupakan keluarga miskin dan rentan yang terdaftar dalam Data Terpadu Program Penanganan Fakir Miskin dan Orang Tidak Mampu. (4). PHK (Pemutus Hubungan Kerja). Dalam persyaratan yang terakhir ini ditujukan kepada para orang tua yang terkena PHK. Dalam kondisi adanya virus corona banyak sekali para pekerja yang terkena PHK (Pemutus Hubungan Kerja). Maka dari itu pada tahun 2020 ada persyaratan baru mengenai PHK (Pemutus Hubungan Kerja).

Jika peserta didik memiliki persyaratan tersebut, maka peserta didik dapat mendaftar Program Indonesia Pintar agar bisa mendapatkan bantuan dana dari pemerintah. Dalam penyeleksian untuk mendapatkan Program Indonesia Pintar dapat melihat bukti-bukti dokumen yang telah di upload oleh siswa, yang nantinya

\footnotetext{
${ }^{12}$ Andela Aggleni, Implementasi Kebijakan Program Kartu Keluarga Sejabtera (KKS) Dalam Meningkatkan Kesejabteraan Masyarakat Miskin Di Kelurahan Sekip Jaya Kecamatan Keminung Kota Palembang, (Jurnal Ilmu Administrasi dan Studi Kebijakan Vol 1 No 1 September 2018), 26
} 
pencairan tersebut akan dikirimkan kepada rekening peserta didik yang telah terdaftar serta yang telah memenuhi persyaratan. Berikut anggaran yang diperoleh peserta didik dalam Program Indonesia Pintar sesuai dengan jenjangnya

Tabel 1.1 Besaran Dana PIP per Siswa yang diperoleh

\begin{tabular}{|l|l|l|}
\hline No & Jenjang & Dana(Rp)/siswa/tahun \\
\hline 1 & Madrasah Ibtidaiyah (MI) & Rp. $450.000,00$ \\
\hline 2 & Madrasah Tsanawiyah (MTs) & Rp. $750.000,00$ \\
\hline 3 & Madrasah Aliyah (MA) & Rp. $1.000 .000,00$ \\
\hline
\end{tabular}

Dalam proses memverivikasi data untuk mendapatkan bantuan pendidikan siswa-siswi harus melengkapi persyaratan yang telah ditentukan. Jika persyaratan tersebut belum terlengkapi maka pihak Kementrian Agama akan mendata dari setiap lembaga. Selanjutnya akan dikonfirmasikan kepada lembaga agar siswa-siswinya mengisi ulang berkas penerima bantuan. Mengenai pengajuan Program Indonesia Pintar lembaga atau madrasah dapat mengajukan siswa-siswinya untuk mendapatkan bantuan melalui aplikasi emis untuk memasukkan data. Kementrian Agama Kabupaten Sidoarjo sebagai perantara dalam penggajuan Program Indonesia Pintar. Berikut ini merupakan langkah-langkah Kemenag dalam memverifikasi data dari lembaga melalui aplikasi emis sebagi berikut:

a. Langkah pertama: Membuka aplikasi emis dengan menggunakan password yang sudah ditentukan setiap kota akan mendapatkan ID dan Passwor sendiri. Selanjutnya akan muncul gambar seperti di bawah ini.

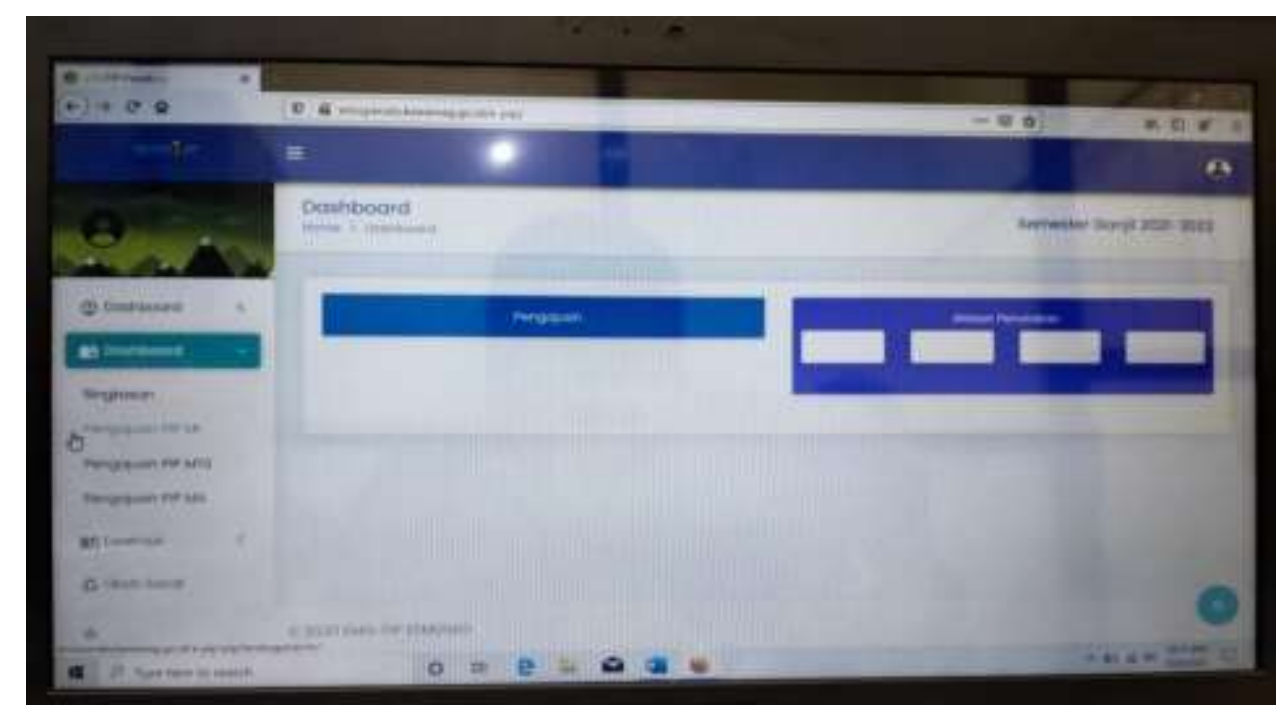




\section{Implementasi Kebijakan Program Indonesia Pintar (PIP) di Wilayah Kementerian Agama Kabupaten Sidoarjo}

b. Langkah kedua: Kemudian akan muncul penampilan di bawah ini dashboard di samping terdapat pilihan pengajuan Program Indonesia Pintar untuk data lembaga seperti MI, MTS, dan MA. Pegawai Kantor Kementrian Agama Kabupaten Sidoarjo melihat data yang madrasah yang di cari.

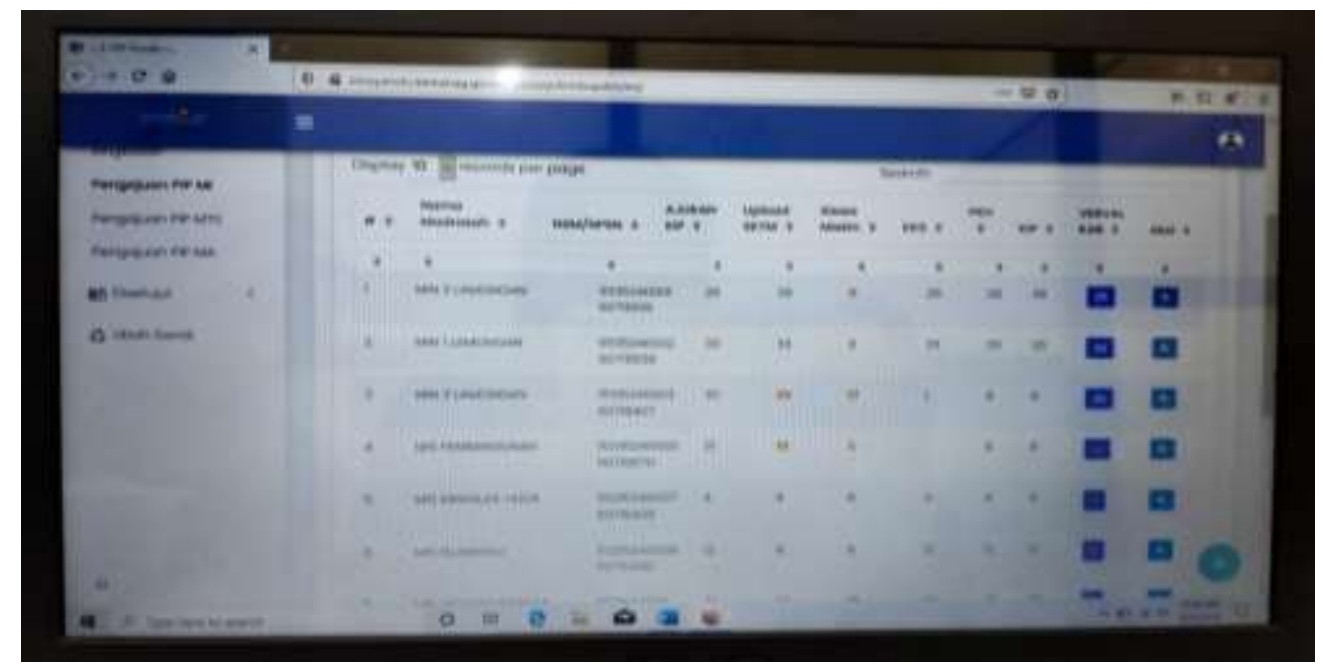

c. Langkah ketiga: Pada aplikasi ini terdapat berbagai pilihan untuk membuka lembaga tersebut. Setelah itu melihat jumlah siswa yang sudah diajukan oleh setiap lembaga.



d. Langkah keempat: Kemudian melihat data siswa- siswi yang sudah di upload, sudahkah sesuai persyaratan yang di tentukan oleh pusat. 


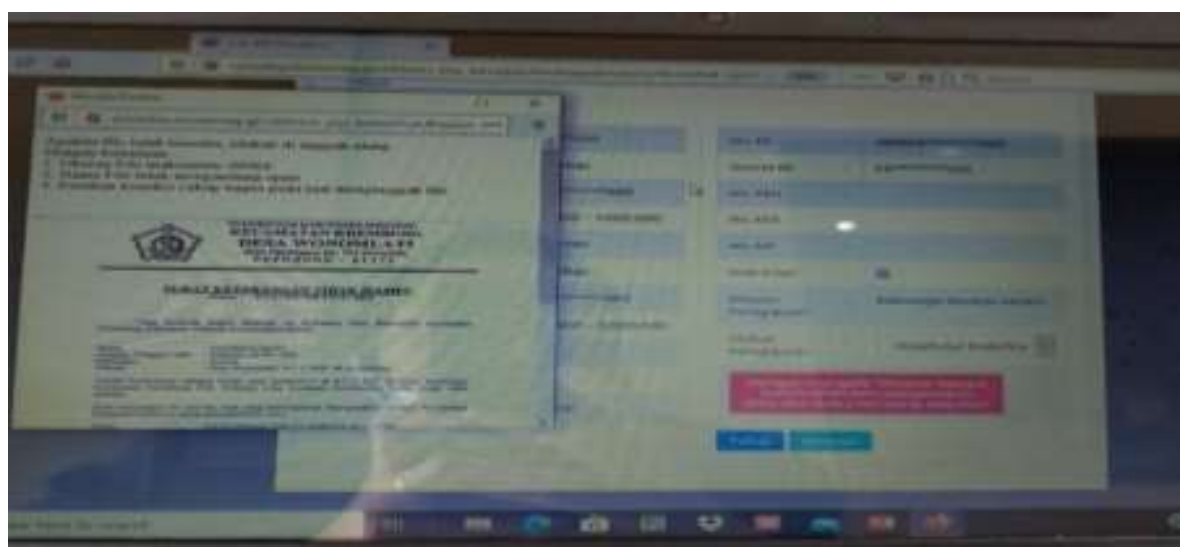

e. Langkah keenam: Gambar di bawah ini menunjukan bahwa data tersebut sudah sesuai persyaratan. Setelah data yang dilihat sudah sesuai persyaratan, maka pegawai dapat memverifikasinya. Jika data tersebut masih belum lengkap pegawai merekap nama lembaga untuk menghubungi lembaga agar segera dilengkap.

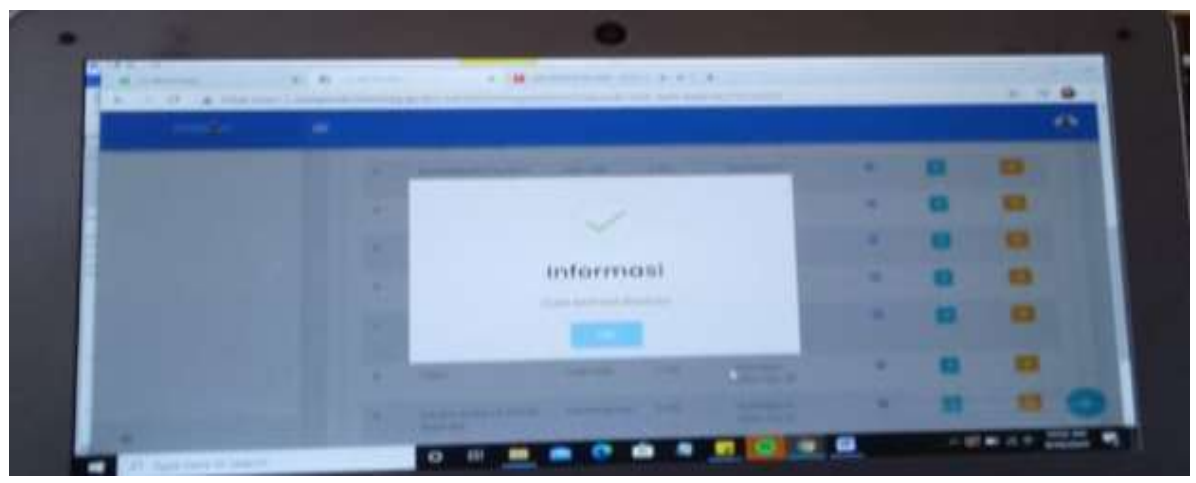

Implementasi kebijakan yang dilakukan oleh Kementerian Agama Kabupaten Sidoarjo adalah menjalankan tugas yang diberikan oleh kementerian pusat untuk menyalurkan dana Program Indonesia Pintar kepada lembaga-lembaga yang siswasiswinya perlu untuk mendapatkan dana dari program tersebut. Tugas yang dilakukan oleh Kementerian Agama Kabupaten Sidoarjo dengan melakukan pelayanan, bimbingan teknis, pembinaan mengenai Program Indonesia Pintar di lembagalembaga mulai dari MI, MTs, dan MA di kabupaten Sidoarjo. Kemenag berhak untuk menyetujui atau memverivkasi data yang telah terdaftar untuk mendapatkan bantuan dari Program Indonesia Pintar.

Pelayanan, bimbingan teknis serta pembinaan mengenai Program Indonesia Pintar yang dilakukan oleh Kementerian Agama Kabupaten Sidoarjo melalui online dan offline, kebanyakan pembinaan mengenai program ini dilakukan melalui grup 


\section{Implementasi Kebijakan Program Indonesia Pintar (PIP) di Wilayah Kementerian Agama Kabupaten Sidoarjo}

Whatsapp. Hal ini karena situasi pandemi covid'19 yang mengharuskan untuk melakukan online. Akan tetapi jika ada permasalahan yang tidak bisa dilakukan dengan cara online maka dilakukan dengan cara offline.

Kebijakan yang telah dibuat oleh pemerintah pusat yaitu kebijakan dengan adanya Program Indonesia Pintar ini diharapkan dapat membantu siswa-siswi keluarga rentan miskin, pemilik kartu $\mathrm{PKH}$, yatim piatu dan keluarga yang mendapatkan musibah seperti Pemutusan Hubungan Kerja (PHK) di masa pandemi covid-19 untuk terus mendapatkan pendidikan dan tidak mengalami putus sekolah.

Kementerian Agama Kabupaten Sidoarjo bertugas untuk memverifikasi ajuanajuan yang telah diajukan oleh lembaga yang ada di Kabupaten Sidoarjo. Dengan demikian agar ajuan tersebut bisa di proses dan diverifikasi oleh pemerintah pusat sehingga dana Program Indonesia Pintar dapat dicairkan. Berbagai temuan peneliti saat memverifikasi ajuan Program Indonesia Pintar (PIP) terdapat beberapa hal yang sangat berpengaruh terhadap proses verifikasi, yaitu: (a). Pada saat memverifikasi terhadap beberapa lembaga yang sama sekali tidak mengisi data-data pengajuan Program Indonesia Pintar (PIP), contoh: nama ayah, nama ibu, NIK, Penghasilan dll tidak ada yang diisi, sehingga pihak kantor Kementerian Agama Kabupaten Sidoarjo tidak bisa memverifikasi ajuan tersebut. (b). Pada saat memverifikasi terdapat lembaga yang belum melengkapi data pengajuan Program Indonesia Pintar (PIP), kasus yang paling sering ditemui oleh peneliti yaitu belum melengkapi data penghasilan orang tua. Sehingga dari situ pihak Kantor Kementerian Agama Kabupaten Sidoarjo tidak bisa memverifikasi ajuan tersebut. (c). Pada saat memverifikasi terdapat dokumen yang sudah diupload oleh lembaga pengajuan, namun pada e-PIP Kementerian Agama Kabupaten Sidoarjo tidak bisa memverifikasi ajuan tersebut. (d). Terdapat double data saat pelaksanaan verifikasi, sehingga menghambat pelaksanaan verifikasi ajuan dana Program Indonesia Pintar tersebut.

Dari keempat permasalahan yang sudah ditemukan oleh peneliti, salah satu yang sering terjadi yaitu dokumen yang telah diupload oleh lembaga pengajuan baik Madrasah Ibtidaiyah (MI), Madrasah Tsanawiyah (MTs) atau Madrasah Aliyah (MA) tidak bisa dibuka oleh pihak Kementerian Agama Kabupaten Sidoarjo. Dengan demikian Kementerian Agama Kabupaten Sidoarjo tidak bisa memverifikasi data tersebut. Permasalahan yang terjadi adalah pada saat pengajuan, upload dokumen 
lembaga melebihi kapasitas yang telah ditentukan, sehingga dokumen tidak bisa dibuka.

Hambatan-hambatan yang sering terjadi ketika proses verifikasi adalah lemotnya jaringan sistem informasi Program Indonesia Pintar, sehingga membutuhkan waktu dan kesabaran dalam pelaksanaan verifikasi. Namun, faktor positif yang bisa diambil dari kegiatan verifikasi Program Indonesia Pintar ini adalah adanya sistem informasi Program Indonesia Pintar ini dapat melakukan verifikasi di mana saja, sehingga ketika pegawai sedang Work From Home tetap bisa melakukan verifikasi.

Pada proses yang dilakukan oleh pihak Kemenag Kabupaten Sidoarjo kemudian di verifikasi ulang oleh pemerintah pusat sehingga dari proses tersebut dapat menyalurkan dana setelah daftar penerima bantuan dana Program Indonesia Pintar telah disetujui.

Dalam proses pengajuan Program Indonesia Pintar meskipun terdapat beberapa hambatan, pengajuan setiap tahun pada Program Indonesia Pintar selalu ada peningkatan jumlah lembaga serta jumlah siswa dari setiap lembaga. Pada proses penyaluran sudah sesuai dengan jadwal dan jumlah yang sama rata sesuai dengan jenjang sekolah siswa. Pencarian dana yang didapatkan oleh setiap siswa dapat dilihat melalui rekening yang telah terdaftarkan sesuai jenjangnya. Setiap tahun selalu ada perbaruan data untuk pengajuan program tersebut.

\section{Kesimpulan}

Berdasarkan hasil penelitian, maka dapat disimpulkan bahwa Implementasi Kebijakan Program Indonesia Pintar (PIP) di Wilayah Kantor Kementrian Agama Kabupaten Sidoarjo sudah sesuai ketentuan dan sudah sesuai harapan. Pertama, proses penyaluran sudah sesuai jadwal. Dalam setahun, Program Indonesia Pintar (PIP) terdapat 4 tahap pencairan dana yang diberikan oleh pemerintah untuk peserta didik sebesar 450.000 untuk jenjang Madrasah Ibtidaiyah(MI), 750.000 untuk jenjang Madrasah Tsanawiyah (MTS), dan 1.000.000 untuk jenjang Madrasah Aliyah (MA) yang nantinya pencairan tersebut akan dikirimkan kepada rekening peserta didik yang telah terdaftar serta yang telah memenuhi persyaratan. Kedua, adanya penyaluran dengan jumlah yang sama rata sesuai dengan jenjang sekolah siswa. Ketiga, setiap 


\section{Implementasi Kebijakan Program Indonesia Pintar (PIP) di Wilayah Kementerian Agama Kabupaten Sidoarjo}

tahun terdapat perbaruan data. Keempat, setiap tahun selalu ada peningkatan jumlah lembaga dan jumlah siswa yang diajukan dalam program PIP di Kementerian Agama Kabupaten Sidoarjo.

Meski demikian, terdapat beberapa kendala dalam implementasi Program Indonesia Pintar di Kementerian Agama Kabupaten Sidoarjo ini, yakni pertama, kurang lengkapnya data pemohon. Hal ini akan memperlambat proses pengajuan PIP. Kedua, jaringan internet PIP Kementerian Agama Kabupaten Sidoarjo sering lemot atau lambat.

Rekomendasi dari penelitian ini adalah agar Program Indonesia Pintar ini bisa dilanjutkan di tahun-tahun berikutnya dan nominal bisa lebih ditingkatkan lagi. Agar masyarakat semua bisa mendapatkan pendidikan yang baik dan layak.

\section{DAFTAR RUJUKAN}

Agusman, Yudi. Implementasi Program Indonesia Pintar di Sekolah Dasar Negeri 1 Kolakaasi Kabupaten Kolaka. (Public Inspiration Jurnal Administrasi Publik. Vol 4 No 2, (2019)

Anggleni, Andela. Implementasi Kebijakan Program Kartu Keluarga Sejabtera (KKS) Dalam Meningkatkan Kesejabteraan Masyarakat Miskin Di Kelurahan Sekip Jaya Kecamatan Kemuning Kota Palembang, (Jurnal: Ilmu Administrasi dan Studi Kebijakan. Vol 1 No 1 September. (2018)

Djoyosuroto, Riska Srihandayani. et. al, Implementasi Program Kartu Indonesia

Pintar (KIP) Di SMA Negeri 2 Dumoga. Jurnal: Manajemen dan Administrasi Publik. Vol 1 No 1 Januari-Maret, (2018).

Mustofa, Ali. dan Prayoga, Andi. Konsepsi Implementasi Sistem Informasi Managemen Dalam Mendukung Pelayanan Tenaga Pendidik. Al-Idaroh: Jurnal Studi Manajemen Pendidikan Islam, Vol 4 No 1 Maret, (2020).

Retnaningsih, Hartini. 2017 Program Indonesia Pintar: Implementasi Kebijakan Jaminan Sosial Bidang Pendidikan Studi di Kota Kupang, Provinsi Nusa Tenggara Timur dan Kota Palembang, Provinsi Sumatera Selatan. (Jurnal Aspirasi Vol 8 No. 2 Desember, (2017).

Rohaeni, N. Eni. dan Saryono, Oyon. Implementasi Kebijakan Program Indonesia Pintar (PIP) Melalui kartu Indonesia Pintar (KIP) dalam Upaya Pemerataan Pendidikan. 
Journal of education management\& administration review Juni. Vol 2 No 1. (2018).

Saraswati, Lilis Novia. Implementasi Kebijakan Program Indonesia Pintar (PIP) Pada Jenjang Sekolah Dasar di Kecamatan Sungai Pinang Kota Samarinda. Jurnal Administrasi Negara, Vol 5 No 4, (2017)

Siyoto, Sandu. Ali Sodik, Dasar Metodologi Penelitian, Yogyakarta: Literasi Media Publishing, 2015

Sugiyono, 2016. Cara Mudah Menyusun Skripsi, Bandung: Penerbit Alfabeta, 2016

Suntoro, Irawan. dll. Kebijakan Publik. Yogyakarta, Graha Ilmu, 2015.

Yusup, Wirastiana Binti. et. al. Evaluasi Indonesia Pintar dalam Peningkatan Akses Pendidikan di Sekolah Menengah Pertama, Jurnal: Manajemen Pendidikan Vol 6 No 1 Januari-Juli ISSN: 2549-9661 (2019)

Zamjani, Irsyad. 2018. Pelaksanaan Program Indonesia Pintar Bagi Penerima Kartu Indonesia Pintar Reguler: Studi di Empat Daerah Kunjungan Kerja Presiden Tabun 2017, Jurnal: Penelitian Kebijakan Pendidikan. Vol 11 No 2 Agustus, (2018). 